\title{
PENGARUH KONFLIK PEKERJAAN KELUARGA, STRES KERJA DAN KOMPENSASI TERHADAP KEPUASAN KERJA PADA KARYAWAN
}

\author{
I Putu Indra Pardita ${ }^{1}$ \\ Ida Bagus Ketut Surya ${ }^{2}$
}

${ }^{1}$ Fakultas Ekonomi dan Bisnis Universitas Udayana (Unud), Bali - Indonesia email: parditaindra1@gmail.com

\begin{abstract}
ABSTRAK
Penelitian ini bertujuan untuk menganalisis pengaruh pemberdayaan karyawan dan konflik pekerjaan keluarga, stres kerja dan kompensasi terhadap kepuasan kerja pada karyawan Alaya Resort jembawan Ubud. Penelitian ini, metode penentuan sampel dilakukan dengan purposive sampling (judgmental sampling) dan diperoleh sebanyak 62 sampel. Teknik analisis yang digunakan adalah analisis regresi linear berganda. Hasil penelitian menunjukkan bahwa konflik pekerjaan keluarga berpengaruh negatif dan signifikan terhadap kepuasan kerja, stres kerja berpengaruh negatif dan signifikan terhadap kepuasan kerja serta kompensasi berpengaruh positif dan signifikan terhadap kepuasan kerja pada karyawan Alaya Resort Jembawan Ubud. Berdasarkan hasil ini, manajemen Alaya Resort Jembawan Ubud diharapkan lebih bijaksana dalam pemberian kompensasi kepada karyawan, serta manajemen juga diharapkan dapat meningkatkan komunikasi kepada karyawan dengan baik sehingga tidak merasa terbebani dengan pekerjaan yang berlebihan.
\end{abstract}

Kata kunci: Konflik Pekerjaan Keluarga, Stress Kerja, Kompensasi, Kepuasan Kerja.

\begin{abstract}
This study aims to analyze the influence of employee empowerment and family work conflicts, work stress and compensation for job satisfaction in employees of Alaya Resort, Ubud. This study, the method of determining the sample was done by purposive sampling (judgmental sampling) and obtained as many as 62 samples. The analysis technique used is multiple linear regression analysis. The results showed that family work conflict had a negative and significant effect on job satisfaction, work stress and a significant and negative effect on job satisfaction and compensation had a positive and significant effect on job satisfaction on employees of Alaya Resort Jembawan Ubud. Based on these results, the management of Alaya Resort Jembawan Ubud is expected to be more prudent in providing compensation to employees, and management is also expected to improve communication with employees so that they do not feel burdened with excessive work.

Keywords: family work conflict, work stress, compensation, job satisfaction.
\end{abstract}




\section{PENDAHULUAN}

Pulau Bali merupakan salah satu destinasi pariwisata dunia. Saat ini Bali telah tumbuh dan berkembang menjadi barometer pariwisata nasional dan internasional. Sektor pariwisata menjadi sektor andalan utama bukan hanya oleh pemerintah daerah saja, namun juga telah menjadi bagian penting dari penopang Pendapatan Nasional. Keberadaan sektor pariwisata sebagai sumber utama Pendapatan Asli Daerah (PAD) di Provinsi Bali tida dapat terlepas dari tingkat kunjungan wisatawan baik domestik maupun mancanegara ke Bali. Berbagai upaya dilakukan pelaku industri pariwisata dan pemerintah dalam meningkatkan kualitas pariwisata guna menunjang peningkatan kedatangan wisatawan ke Bali.

Jumlah wisman ke Provinsi Bali pada bulan Januari 2019 turun sebesar 8,54 persen dibandingkan dengan catatan bulan Desember 2018. Bila dibandingkan dengan bulan Januari 2018, jumlah wisman ke Bali tercatat mengalami peningkatan sebesar $27,41 \%$. Sementara menurut kebangsaan, wisman yang tercatat paling banyak datang ke Bali pada bulan Januari 2019 yaitu wisman dengan kebangsaan Tiongkok (24,94\%), Australia (20,94\%), India (6,30\%), Amerika Serikat $(3,85 \%)$ dan Rusia (3,59\%). Tingkat Penghunian Kamar (TPK) hotel berbintang bulan Januari 2019 tercatat mencapai 53,27\%, mengalami penurunan sebesar $-4,35$ poin dibandingkan TPK bulan sebelumnya yang mencapai 57,62\%. Jika dibandingkan bulan Januari 2018 yang mencapai 52,97\%, tingkat penghunian kamar di bulan Januari 2019, tercatat meningkat 0,30 poin. Data BPS juga menyatakan bahwa kunjungan wisatawan senantiasa mengalami perubahan yang bersifat fluktuatif. Adapun data jumlah kunjungan wisatawan ke Bali selama kurun waktu 2013 hingga 2018 adalah seperti pada Tabel 1.

Tabel 1.

Jumlah Kunjungan Wisatawan ke Bali Tahun 2013 - 2018

\begin{tabular}{llccccc}
\hline Bulan & $\mathbf{2 0 1 3}$ & $\mathbf{2 0 1 4}$ & $\mathbf{2 0 1 5}$ & $\mathbf{2 0 1 6}$ & $\mathbf{2 0 1 7}$ & $\mathbf{2 0 1 8}$ \\
\hline Januari & 232,935 & 279,257 & 301,748 & 350,592 & 460,824 & $358,065.00$ \\
Pebruari & 241,868 & 275,795 & 338,991 & 375,744 & 453,985 & $452,423.00$ \\
Maret & 252,210 & 276,573 & 305,272 & 364,113 & 425,499 & $492,678.00$ \\
April & 242,369 & 280,096 & 313,763 & 380,767 & 477,464 & $516,777.00$ \\
Mei & 247,972 & 286,033 & 295,973 & 394,557 & 489,376 & $528,512.00$ \\
Juni & 275,667 & 330,396 & 359,702 & 405,835 & 504,141 & $544,550.00$ \\
Juli & 297,878 & 361,066 & 382,683 & 484,231 & 592,046 & $624,366.00$ \\
Agustus & 309,219 & 336,763 & 303,621 & 438,135 & 601,884 & $573,766.00$ \\
September & 305,629 & 354,762 & 389,060 & 445,716 & 550,520 & $555,903.00$ \\
Oktober & 266,562 & 341,651 & 369,447 & 432,215 & 465,085 & $517,889.00$ \\
Nopember & 307,276 & 296,876 & 270,935 & 413,232 & 361,006 & $406,725.00$ \\
Desember & 299,013 & 347,370 & 370,640 & 442,800 & 315,909 & $498,819.00$ \\
Jumlah /Total: & $3,278,598$ & $3,766,63$ & $4,001,83$ & $4,927,93$ & $5,697,73$ & $6,070,473$ \\
Pertumbuhan & 11.16 & 14.89 & 6 & 7 & 9 & \\
/Growth(\%) & & & 5.24 & 23.14 & 15.62 & 6.54 \\
\hline Sumber: BPS Prov & & & & & \\
\hline
\end{tabular}

Sumber: BPS Provinsi Bali, 2018

Tabel 1. menunjukkan bahwa terjadi fluktuasi kunjungan wisatawan ke Bali, dimana data menunjukkan bahwa peningkatan jumlah wisatawan terjadi pada tahun 2013 dan 2014, namun pada tahun 2015 terjadi penurunan. Kunjungan 
wisatawan kembali meningkat di tahun 2016 namun kembali mengalami penurunan pada 2 tahun berikutnya yakni taun 2017 dan 2018.

Pemerintah Daerah (Pemda) serta pelaku-pelaku bisnis pada industri pariwisata senantiasa melakukan upaya perbaikan guna menjaga stabilitas pariwisata di Bali. Berbagai jasa akomodasi pariwisata dibangun sebaai salah satu bentuk perkembangan dan upaya penunjang pariwisata di Bali. Mulai dari pembangunan hotel-hotel berbintang dan bertaraf internasional, pembangunan villa, resort, serta akomodasi wisata lainnya kini berkembang pesat di Bali.

Kabupaten Gianyar merupakan salah satu Kabupaten yang menjadi daerah tujuan pariwisata di Bali. Kabupaten Gianyar dikenal sebagai Kota Seni, berbagai produk kesenian berkembang pesat dan menjadi bagian dari keseharian masyarakat di Kabupaten Gianyar. Keunikan adat dan budaya, serta keanekaragaman seni yang ada di Kabupaten Gianyar menjadikan Kabupaten Gianyar sebagai salah satu destinasi pariwisata budaya di provinsi Bali. pertumbuhan pariwisata di Kabupaten Gianyar sejalan dengan tingginya Tingkat Penghunian Kamar hotel (TPK) di hotel-hotel atau penyedia jasa akomodasi pariwisata di Kabupaten Gianyar. Tabel 2. merupakan Tabel data Tingkat Penghunian Kamar hotel (TPK) di hotel-hotel atau penyedia jasa akomodasi pariwisata di Bali pada kurun waktu bulan nopember hingga desember 2018.

Tabel 2.

Tingkat Penghunian Kamar (TPK) Hotel Berbintang di Bali Bulan Nopember s/d Desember 2018

\begin{tabular}{clrcc}
\hline No. & Kabupaten/Kota & Tingkat Penghunian Kamar (TPK) & Perubahan (Poin) \\
\hline 1 & Badung & 58,11 & 59,38 & 1,27 \\
2 & Gianyar & 44,70 & 48,32 & 3,63 \\
3 & Karangasem & 34,23 & 32,93 & 1,30 \\
4 & Bulelang & 34,99 & 37,13 & 2,14 \\
5 & Denpasar & 55,78 & 56,78 & 1,15 \\
& Bali & 55,92 & 57,62 & 1,70 \\
\hline
\end{tabular}

Sumber: BPS Provinsi Bali, 2018

Tabel 2. menunjukkan bahwa Kabupaten Gianyar menjadi Kabupaten dengan Tingkat Penghunian Kamar (TPK) tertinggi ketiga di Provinsi Bali. Sementara Kabupaten Badung menjadi Kabupaten dengan TPK tertinggi dan Kota Denpasar dengan TPK tertinggi ketiga. Data tersebut menguatkan bahwa Gianyar merupakan salah satu barometer pariwisata khususnya wisata seni dan budaya di Provinsi Bali.

Alaya Resort Jembawan Ubud merupakan resort yang berlokasi di jantung kota Gianyar yakni di Desa Ubud, Kecamatan Ubud, Kabupaten Gianyar. Kawasan pariwisata Ubud identik dengan seni, budaya serta keindahan alam pedesaan. Alaya Resort Jembawan Ubud merupakan sebuah resort yang memiliki nuansa yang berbeda dibandingkan dengan hotel-hotel ataupun resort lain yang berada di kota Ubud. Keindahan alam menjadi nilai utama yang ditawarkan oleh resort ini.

Sumber daya manusia senantiasa melekat pada setiap perusahaan sebagai faktor penentu keberadaan dan berperan dalam memberikan kontribusi ke arah 
pencapaian tujuanperusahaan secara efektifdan efisien.Perusahaan yang bergerak di bidang jasa akomodasi pariwisata, keberadaan sumber daya manusia (SDM) menjadi salah satu fokus perhatian manajemen Alaya Resort Jembawan Ubud. Perusahaan membutuhkan sumber daya manusia yang handal dan berkualitas sehingga perusahaan harus dapat mengelola dan memperhatikan sumber daya manusia dengan sebaik mungkin (Waspodo dkk., 2013). Perusahaan dituntut mampu memberikan pelayanan terbaik kepada para wisatawan yang menginap dan karyawan dituntut mampu memberikan kinerja yang optimal bagi perusahaan, sehingga dapat meningkatkan citra perusahaan, agar wisatawan yang menginap di resort merasa terlayani dengan baik dan merasa puas.

Karyawan dituntut untuk mampu memberikan pelayanan prima kepada wisatawan, dan disisi lain perusahaan (Alaya Resort Jembawan Ubud) juga dituntut mampu memberikan kompensasi yang setimpal sehingga karyawan juga merasaan kepuasan kerja atas apa yang telah mereka berikan kepada perusahaan. Kepuasan kerja memiliki peranan bagi Alaya Resort Jembawan Ubud untuk dapat mencapai kualitas pekerjaan yang baik mengingat resort ini memerlukan karyawan yang memiliki sifat puas dalam menyelesaikan pekerjaannya. Studi pendahuluan (riset awal/pra riset) yang dilakukan peneliti terhadap beberapa karyawan di Alaya Resort Jembawan Ubud menunjukkan bahwa peran tenaga kerja dalam menyelesaikan tugasnya masih kurang dikarenakan masih terdapat 20 orang karyawan dari tota 80 orang karyawan yang merasa tidak puas dengan pekerjaan yang masih diberikan manajer. Adapun data alasan ketidakpuasan kerja karyawan yang bekerja di Alaya Resort Jembawan berdasarkan informasi yang Penulis dapat dari Kepala Divisi Sumber Daya Manusia Manusia (Human Resource Development/HRD) Alaya Resort Jembawan Ubud yakni seperti pada Tabel 3.

\section{Tabel 3.}

Alasan Ketidakpuasan Kerja Karyawan Alaya Resort Jembawan

\begin{tabular}{|c|c|c|}
\hline No & $\begin{array}{c}\text { Jumlah } \\
\text { Karyawan }\end{array}$ & Masalah dari Karyawan \\
\hline 1 & 7 Karyawan & $\begin{array}{l}\text { Karyawan tidak merasa nyaman dalam melakukan } \\
\text { pekerjaannya dikarenakan terlibat konflik dengan } \\
\text { keluarganya yang bersifat eksternal dari perusahaan. }\end{array}$ \\
\hline 2 & 3 Karyawan & $\begin{array}{l}\text { Karyawan tidak merasa puas dengan pekerjaannya } \\
\text { dikarenakan upah yang diberikan tidak sesuai dengan } \\
\text { pekerjaannya. }\end{array}$ \\
\hline 3 & 4 Karyawan & $\begin{array}{l}\text { Karyawan tidak merasa puas dikarenakan tidak di } \\
\text { promosikan naik jabatan oleh manajer. }\end{array}$ \\
\hline 4 & 6 Karyawan & Karyawan tidak merasa cocok dengan rekan kerjanya. \\
\hline Jumlah & 20 Karyawan & \\
\hline
\end{tabular}

Sumber: Human Resource Development (HRD) Alaya Resort Jembawan Ubud, 2018

Tabel 3. merupakan hasil prariset yang menunjukkan bahwa terdapat beberapa masalah dalam karyawan Alaya Resort Jembawan Ubud yang bisa dikatakan sifat kepuasan kerja karyawan masih cukup rendah. Berdasarkan data Human Resource Development (HRD) Alaya Resort Jembawan Ubud, menyatakan bahwa terdapat total terdapat 80 Karyawan di Alaya Resort 
Jembawan Ubud yang terdiri dari 62 Karyawan Tetap dan sudah berstatus kawin (sudah menikah), sementara sisanya 18 orang karyawan merupakan karyawan tidak tetap (kontrak). Tabel 3 menunjukkan bahwa 7 dari 20, karyawan tidak merasa nyaman dalam melakukan pekerjaannya dikarenakan terlibat konflik dengan keluarganya yang bersifat eksternal dari perusahaan. Selanjutnya, terdapat 3 dari 20 karyawan tidak merasa puas dengan pekerjaannya dikarenakan upah yang diberikan tidak sesuai dengan pekerjaannya. 4 dari 20, karyawan tidak merasa puas dikarenakan tidak di promosikan naik jabatan oleh manajer dan 6 dari 20, Karyawan tidak merasa cocok dengan rekan kerjanya karena adanya permasalahan pribadi dengan sesama rekan kerjanya. Permasalahan terkait dengan rendanya kepuasan kerja menjadi salah satu permasaahan utama yang dihadapi oleh Alaya Resort Jembawan Ubud yang tentunya menjadi fokus perhatian manajemen perusahaan.

Rendahnya tingkat kepuasan kerja karyawan dapat mengakibatkan dampak negatif bagi perusahaan seperti dapat mengurangi produktifitas rekan kerja, dapat mengurangi produktifitas manajerial, dan dapat mengurangi efisiensi penggunaan sumber daya organisasi. Kepuasan kerja sangat mempengaruhi karyawan didalam melakukan pekerjaan. Putra \& Wibawa (2014). menyatakan bahwa kepuasan kerja merupakan suatu sikap seseorang karyawan terhadap tugas yang didapat. Jika seseorang karyawan memiliki tingkat kepuasan yang tinggi terhadap pekerjaannya, maka karyawan tersebut memiliki produktivitas kerja yang baik.

Wibowo (2016) menyatakan kepuasan kerja akan mempengaruhi produktivitas yang sangat dihadapkan oleh manajer, oleh sebab itu menejer perlu memahami apa yang harus dilakukan untuk meningkatkan kepuasan kerja karyawan. Kepuasan kerja adalah penilaian dari para pekerja tentang seberapa jauh pekerjaanya secara keseluruhan memuaskan kebutuhannya (Rivai \& Sagala, 2011). Kepuasan kerja memiliki hubungan searah apabila dikaitkan dengan kinerja yang lebih produktif (Noor dkk., 2014). Kepuasan kerja memegang peran penting bagi organisasi karena kepuasan kerja merupakan kriteria dalam menentukan keberhasilan organisasi dalam memenuhi kebutuhan para anggotanya. Karyawan yang puas dengan pekerjaan mereka cenderung lebih kreatif dan inovatif yang membantu bisnis untuk tumbuh, berkembang dan membawa perubahan positif sesuai dengan situasi pasar dan dengan demikian membuat organisasi mampu bersaing di tingkat internasional.

Faktor-faktor yang mempengaruhi kepuasan kerja adalah faktor psikologi, faktor sosial, faktor fisik, dan faktor finansial. Faktor fisikologi adalah faktor yang meliputi dan berhubungan dengan kejiwaaan karyawan. Faktor sosial merupakan faktor yang berhubungan dengan interaksi sosial seorang karyawan. Faktor fisik merupakan faktor yang berhubungan dengan kondisi fisik karyawan dan kondisi lingkungan fisik kerja karyawan. Faktor finansial merupakan faktor yang berhubungan dengan kesejahteraan karyawan. Salah satu faktor psikologis yang mempengaruhi kepuasan kerja karyawan adalah stres kerja. Hal tersebut senada hasil penelitian Praptini (2001) menunjukkan bahwa faktor-faktor yang mempengaruhi kepuasan kerja salah satunya adalah stres kerja. Stres kerja karyawan timbul akibat dari kepuasan kerja tidak terwujud dari pekerjaannya. Stres sebagai reaksi individu, yang dapat berupa reaksi fisologi, pisikologis, atau 
perilaku. Velnampy (2013) mendefinisikan stres kerja sebagai sebuah pola emosional perilaku kognitif dan reaksi psikologis terhadap aspek yang merugikan dan berbahaya dari setiap pekerjaan, organisasi kerja dan lingkungan kerja.

Stres kerja adalah perasaan yang menekan atau merasa tertekan yang dialami karyawan dalam menghadapi pekerjaan. Putra \& Wibawa (2014) menjelaskan definisi stres kerja adalah suatu kondisi karyawan yang mengalami tekanan dalam pekerjaan baik dari tugas, pimpinan dan lingkungan kerja tempat karyawan tersebut bekerja. Karyawan yang mengalami stres kerja akan cenderung tidak produktif kinerjanya (Karambut \& Noormijati, 2015). Hasibuan (2016) menjelaskan orang-orang yang mengalami stres akan menjadi gugup serta merasakan kekuatiran kronis sehingga mereka akan menjadi marah-marah, agresif, tidak dapat relaks, dan memperlihatkan sikap yang tidak kooperatif.

Stres sebagai suatu istilah payung yang merangkumi tekanan, beban, konflik, keletihan, ketegangan, panik, perasaan gemuruh, kemurungan dan hilang daya. Stres kerja adalah suatu kondisi ketegangan yang menciptakan adanya ketidakseimbangan fisik dan psikis, yang mempengaruhi emosi, proses pikir, dan kondisi seorang karyawan. Stres yang terlalu besar dapat mengancam kemampuan seseorang untuk menghadapi lingkungan. Sebagai hasilnya, pada diri karyawan berkembang berbagai macam gejala stress yang dapat mengganggu pelaksanaan kerja mereka (Rivai \& Sagala, 2011).

Yekti \& Wulandari (2010) menyatakan beberapa akibat yang nampak jika seseorang sedang mengalami stress antara lain: kelelahan dalam bekerja, psikomatis (terganggunya mental dan fisik seseorang), trauma serta kelelahan kepedulian. Sementara Cox dalam Pangewa (2005) mengungkapkan bahwa stress dapat mengakibatkan beberapa hal, yakni: akibat subjektif (kegelisahan, kebosanan), akibat perilaku (emosi tidak stabil), akibat kognitif (kurang konsentrasi, kurang bisa mengambil keputusan), akibat fisiologis (naiknya tekanan darah), serta akibat keorganisasian (menyebabkan kinerja menjadi rendah).

Hasibuan (2016) juga menjelaskan bawa faktor-faktor yang menyebabkan stress kerja diantaranya adalah beban kerja yang berlebihan, sikap pemimpin yang kurang adil, waktu dan peralatan yang kurang memadai, konflik dengan kelompok kerja, upah yang terlalu rendah, masalah-masalah eksternal pekerjaan, dan lainlain. Ardana dkk. (2013) menyatakan sumber stres antara lain meliputi faktorfaktor yang melekat pada pekerjaan, peranan dalam organisasi, hubunganhubungan dalam organisasi, perkembangan karir, struktur dan iklim organisasi, hubungan organisasi dengan pihak luar, faktor dari dalam individu yang bersangkutan, dan kepemimpinan.

Penelitian Praptini (2001) yang menunjukkan bahwa stress berpengaruh terhadap kepuasan kerja, namun hasil penelitian. Namun, hasil penelitian Luthan (2008) menunjukkan bahwa stres kerja tidak berpengaruh terhadap kepuasan kerja karyawan. Penelitian Mansoor et al. (2014) stres berhubungan negatif dengan kepuasan kerja. rendahnya tingkat kepuasan kerja karyawan menjadi sumber stres, sementara kepuasan yang tinggi dapat meringankan efek stres, hal tersebut berarti bahwa stres dan kepuasan kerja saling terkait (Bhatti et al. 2011). Stres menjadi 
masalah utama dalam bekerja yang sangat berhubungan dengan kepuasan (Jehangir et al. 2011).

Selain stres kerja permasalahan yang juga sangat mempengaruhi kepuasan kerja karyawan adalah konflik kerja. Konflik kerja dapat berupa adanya konflik antar keluarga, karyawan yang sudah berkeluarga sangat sulit untuk melakukan pekerjaannya dikarenakan beban yang dimiliki terlalu banyak. Konflik adalah suatu perselisihan atau perjuangan diantara dua pihak yang ditandai dengan menunjukkan permusuhan secara terbuka, dan atau mengganggu dengan sengaja pencapaian tujuan pihak yang menjadi lawannya. Gangguan yang dilakukan dapat meliputi usaha-usaha yang aktif atau penolakan pasif. Dalam sebuah perusahaan konflik sosial juga dapat dirasakan oleh seluruh lapisan pegawai.

Slocum \& Helriegel (2007) mendefinisikan konflik mengacu pada satu proses dimana satu pihak (orang atau kelompok) merasakan tujuannya sedang ditentang atau secara negatif dipengaruhi oleh pihak lain). Henry (2009) menyatakan terdapat dua tipe dasar konflik: (1) Konflik Tugas (Task Conflict). Perselisihan anggota kelompok tentang substansi diskusi disebut konflik tugas (task conflict). Konflik Tugas mungkin menjadi produktif dengan cara meningkatkan kualitas keputusan dan proses berpikir kritis. Area potensial yang lain untuk konflik adalah hubungan ntar pribadi di dalam organisasi; (2) Konflik Hubungan (Interpersonal/Relationship Conflict).

Konflik pekerjaan-keluarga (work family conflict) adalah tuntutan peran dua arah di mana tuntutan pekerjaan mengganggu tuntutan keluarga atau tanggung jawab misalnya tanggung jawab peduli keluarga terganggu dengan tanggung jawab yang berhubungan dengan pekerjaan yang menciptakan beberapa hasil yang tidak diinginkan seperti stres, kesehatan yang buruk, konflik yang berhubungan dengan pekerjaan, ketidakhadiran dan turnover. Konflik pekerjaankeluarga merupakan pertentangan yang terjadi akibat adanya dua kepentingan yang tidak sejalan didalam lingkungan rumah tangga dan organisasi. Tuntutan peran keluarga yang berlebihan sering berdampak pada peran dalam dunia kerja. Work-Family Conflict akan menurunkan kinerja, produktivitas dan kepuasan kerja.

Beberapa studi penelitian terdahulu telah meneliti hubungan konflik pekerjaan-keluarga dengan kepuasan kerja, namun hasil penelitiannya masih beragam atau inkonsisten. Menurut Soeharto (2010) dalam penelitian mengenai konflik pekerjaan-keluarga dengan kepuasan kerja: metaanalisis, didapati bahwa ada hubungan negatif konflik pekerjaan-keluarga dan konflik keluargapekerjaan/Work Family Conflict dengan kepuasan kerja. Berbeda dari penelitian Susanto (2010) menemukan bahwa konflik kerja-keluarga tidak mempunyai pengaruh negatif yang signifikan terhadap kepuasan kerja. Penelitian Churiyah (2011) menyatakan adanya hubungan negatif antara work-family conflict dan kepuasan kerja yang akan berdampak pada kinerja. Penelitian yang dilakukan Grandey et al. (2005) melaporkan konflik pekerjaan-keluarga berhubungan negatif dengan kepuasan kerja. Menurut Lathifah \& Rohman (2014) mengemukakan bahwa, jika kepuasan kerja sudah dirasa kurang oleh seseorang, maka akan muncul keinginan untuk keluar dari perusahaan tempat mereka bekerja. 
Setiap karyawan yang bekerja pada suatu perusahaan, pernah mengalami konflik pekerjaan-keluarga, stress kerja serta masalah kompensasi yang juga merupakan salah satu faktor yang mempengaruhi kepuasan kerja karyawan. Masalah kompensasi merupakan salah satu faktor finansial yang menjadi faktor yang mempengaruhi kepuasan kerja karyawan. Masalah tekait kompensasi finasial merupakan sebuah isu pelik dalam hubungan industrial perusahaan dan karyawan perusahaan. Karyawan selaku pekerja cenderung sensitif akan isu kompensasi finansial yang diterimanya, apakah kompensasi finansial yang diberikan perusahaan telah sebanding dengan input yang dia berikan terhadap perusaaan itu sendiri. Disisi lain, terkadang manajemen perusahaan juga menentukan tarif atau kompensasi finansial yang terlalu rendah dengan tujuan efisiensi dan efektivitas, namun hal tersebut memicu protes dari karyawan. Protes terhadap rendahnya kompensasi finansial yang diterima oleh seorang karyawan akan memicu menurunnya stabititas kerja karyawan akibat ketidakpuasan yang dirasakan

Kompensasi kepada karyawan akan memberikan kepuasan kerja tersendiri untuk karyawan, apabila seorang karyawan mendapatkan kompensasi yang pantas atas apa yang sudah dikerjakan pada perusahaan maka karyawan tersebut juga akan mendapatkan kepuasan kerja yang baik (Hasibuan, 2016). Kompensasi merupakan suatu imbalan yang diberikan oleh perusahaan kepada para karyawan atas pekerjaan yang dihasilkannya.

Rivai \& Sagala (2011) kompensasi terdapat dua macam, yaitu kompensasi finansial dan kompensasi non finansial. Pemberian kompensasi kepada karyawan harus layak dan adil, karena dapat meningkatkan kemampuan karyawan dalam meningkatkan produktivitas kerjanya, hal tersebut dikarenakan karyawan dapat merasakan kepuasan dalam melaksanakan pekerjaannya. Pemberian kompensasi kepada karyawan harus layak dan adil, karena dapat meningkatkan kemampuan karyawan dalam meningkatkan produktivitas kerjanya, hal tersebut dikarenakan karyawan dapat merasakan kepuasan dalam melaksanakan pekerjaannya.

Hasil penelitian Prawitasari et al. (2015) kompensasi memiliki pengaruh signifikan secara simultan terhadap kepuasan kerja pegawai pada PT. Dunia Garmen Internasional Denpasar dengan kontribusi sebesar 19,8\%. Penelitian yang dilakukan oleh Nazir et al. (2013) yang menyatakan bahwa kompensasi berpengaruh positif terhadap kepuasan kerja. Rood \& Holdnak (2013) juga menyatakan bahwa kompensasi berpengaruh positif dan signifikan terhadap kepuasan kerja. Sama halnya dengan Adeoye \& Fields (2017), Salisu et al. 2016), dan Muguongo (2015) yang menyatakan bahwa kompensasi dan kepuasan kerja berpengaruh positif dan signifikan terhadap kepuasan kerja.

Teori yang menjelaskan hubungan antara konflik pekerjaan keluarga terhadap kepuasan kerja adalah Work/family Border-Crossing Theory (teori border). Teori border (batas) mendeskripsikan bagaimana ketika konflik tetap ada dan menyediakan suatu kerangka untuk indi- vidu dan organisasi bernegosiasi untuk mencapai keseimbangan kerja keluarga.

Work to Family Conflict adalah jenis resistensi tekanan peran yang muncul dari tempat kerja dan mempengaruhi lingkup keluarga dan saling bertentangan. Penyebab konflik pekerjaan-keluarga berasal dari faktor kepribadian seseorang 
seperti harga diri, sementara efek dari konflik pekerjaan- keluarga terpusat pada kepuasan seseorang terhadap pekerjaan, kesejahteraan keluarga.

Penelitian Malik et al., (2012) menunjukkan kepuasan kerja dalam menjalankan fungsinya tidak berdiri sendiri, tetapi berhubungan dengan kinerja dan tingkat imbalan, dipengaruhi oleh ketrampilan, kempuan dan sifat-sifat individu. Handoko (2011) menyatakan kepuasan kerja adalah keadaan emosional yang menyenangkan atau tidak menyenangkan para karyawan memandang pekerjaan mereka. Shurbagi (2014) berpendapat bahwa kepuasan kerja merupakan cara pandang seseorang baik yang bersifat positif maupun negatif tentang pekerjaannya.

Hasil penelitian Kurnia (2016) menyatakan bahwa konflik pekerjaankeluarga memiliki pengaruh negatif dan signifikan terhadap terhadap kepuasan kepuasan kerja. Konflik pekerjaan-keluarga akan lebih mempengaruhi kepuasan kerja wanita dari pada pria. Berdasarkan hasil studi metaanalisis yang dilakukan oleh Soeharto (2010) menyatakan bahwa terdapat hubungan negatif antara konflik pekerjaan-keluarga dengan kepuasan kerja. Penelitian juga mengatakan bahwa terdapat hubungan yang negatif dan sangat signifikan antara Konflik pekerjaankeluarga dengan kepuasan kerja (Prawitasari \& Purwanto, 2007). Penelitian lain juga mengatakan bahwa konflik pekerjaan-keluarga memiliki hubungan negatif dan signifikan terhadap kepuasan kerja (Nawab \& Iqbal, 2013).

Penelitian Ding et al. (2018) menunjukkan bahwa kepuasan kerja dan pekerjaan - konflik keluarga antara perawat di masyarakat dan sektor khusus tidak memiliki perbedaan signifikan dan kepuasan kerja di antara perawat adalah ratarata. Meningkatkan pekerjaan kepuasan perawat dan mengurangi jumlah pekerjaan dengan keluarga mereka meningkatkan kualitas kerja perawat. Umumnya, disarankan agar lebih banyak penelitian dalam bidang kepuasan kerja perawat dan konflik keluarga-kerja harus dilakukan, karena mereka mengarah untuk mengidentifikasi faktor laten dalam pengabaian pekerjaan perawat dan peningkatan mereka keberlanjutan dalam pekerjaan mereka (Nayeri et al. 2018). Survei dilakukan dengan sampel 138 guru perempuan Punjab, menyimpulkan bahwa peningkatan kerja emosional meningkat konflik keluarga antar karyawan. Artinya, itu berdampak negatif pada Work Family Conflict (WFC). Sedangkan supervisor yang mendukung mengurangi konflik Keluarga Kerja dengan secara positif mempengaruhinya. Di sisi lain, konflik keluarga bekerja menyebabkan penurunan komitmen organisasi karena berdampak secara negatif.

Konflik Pekerjaan-Keluarga atau Work family conflict dihubungkan dengan penurunan kepuasan kerja, penyesuaian kehidupan keluarga yang rendah, penurunan kepuasan dalam karir dan keluarga dan meningkatnya tekanan hidup. Penelitian sebelumnya dilakukan Rantika \& Sunjoyo (2011), Karimi et al. (2012), Rathi \& Barath (2013), Lathifah \& Rohman (2014), Anafarta (2011), Laksmi \& Hadi (2012) berpendapat bahwa konflik pekerjaan- keluarga berpengaruh negative terhadap kepuasan kerja seseorang dalam bekerja. Semakin tinggi konflik pekerjaan-keluarga yang dirasakan oleh seorang karyawan maka kepuasan kerjanya akan semakin rendah, begitupula sebaliknya semakin rendah konflik pekerjaan-keluarga yang dirasakan maka kepuasan kerjanya akan semakin tinggi. 
Berdasarkan hasil penelitian sebelumnya, hipotesis yang dapat diajukan dalam penelitian ini adalah:

$\mathrm{H}_{1}$ : Konflik Pekerjaan-Keluarga memiliki pengaruh negatif signifikan terhadap Kepuasan Kerja

Teori yang menjelaskan hubungan antara stress kerja terhadap kepuasan kerja adalah Conservation of Resources (COR) Theory. Conservation of Resources (COR) theory merupakan sebuah teori yang dikembangkan oleh Stevan Hobfoll, teori yang menjelaskan bahwa seseorang akan berusaha untuk memperoleh dan menjaga atau mempertahankan sumber daya yang dimilikinya, sumber daya disini meliputi energi (waktu). Waktu merupakan hal yang penting yang dibutuhkan oleh karyawan didalam melakukan pekerjaan, karyawan yang memiliki waktu yang terbatas dan dituntut melakukan pekerjaan yang sangat banyak, akan membuat karyawan kehilangan sumber daya tersebut dan mengakibatkan keadaan negatif, seperti mengalami stres.

Faktor-faktor yang mempengaruhi kepuasan kerja salah satunya adalah stress kerja. Salah satu dampak stress kerja secara pisikologis dapat menurunkan kepuasan kerja karyawan, terlebih lagi dampak dari stress terhadap kepuasan adalah secara langsung. Mansoor et al. (2014) menyatakan bahwa stress kerja berpengaruh negatif dan signifikan terhadap kepuasan kerja. Tunjungansari (2011) dan Potale (2015) menunjukan bahwa stress kerja memiliki pengaruh signifikan terhadap kepuasan kerja, hal ini juga sesuai dengan pendapat Handoko (2011) bahwa kepuasan kerja penting untuk aktualisasi diri, karyawan yang tidak memperoleh kepuasan kerja tidak akan pernah mencapai kematangan pisikologis dan pada gilirannya akan menimbulkan frustasi yang merupakan dampak dari stress pada pekerjaan. Penelitian menunjukan adanya hubungan negatif kuat antara perasaan stress dengan kepuasan kerja (Wibowo, 2016).

Berdasarkan hasil penelitian sebelumnya, hipotesis yang dapat diajukan dalam penelitian ini adalah:

$\mathrm{H}_{2}$ : Stres Kerja memiliki pengaruh negatif dan signifikan terhadap Kepuasan Kerja

Pengaruh kompensasi terhadap kepuasan kerja dijelaskan oleh teori kepuasan kerja yakni teori dua keadilan (equity theory). Teori Keadilan (Equity Theory) menyatakan bahwa puas atau tidak puasnya pegawai merupakan hasil dari membandingkan antara input-outcome dirinya dengan pegawai lain. Jadi, jika perbandingan tersebut dirasakan seimbang, maka pegawai tersebut akan merasa puas. Tetapi, apabila terjadi ketidakseimbangan, maka akan dapat menyebabkan dua kemungkinan, yaitu over compensation inequity (ketidakseimbangan yag menguntungkan diriya sendiri) dan sebaliknya under compensation inequity (ketidakseimbangan yang meguntungkan pegawai lain yang menjadi pembanding).

Wibowo (2016) mendefinsikan kompensasi merupakan kontra prestasi terhadap penggunaan tenaga atau jasa yang telah diberikan oleh tenaga kerja. Berkaitan dengan pengaruh kompensasi terhadap kepuasan kerja, Simamora (2004) menyebutkan kepuasan (satisfaction) merupakan istilah evaluatif yang menggambarkan suatu sikap suka atau tidak suka. Kepuasan bayaran (pay satisfaction), oleh karenanya, mengacu pada sikap suka dan tidak suka terhadap 
sistem kompensasi organisasi.

Hasil penelitian Supatmi dkk. (2013) membuktikan bahwa kompensasi berpengaruh signifikan terhadap kepuasan kerja karyawan. Artinya kompensasi berpengaruh secara bermakna terhadap kepuasan kerja karyawan. Hubungan dua variabel ini juga positif dimana semakin tinggi kompensasi yang diterima karyawan maka akan semakin tinggi pula kepuasan kerja yang dirasakan karyawan. Kompensasi kepada karyawan akan memberikan kepuasan kerja tersendiri untuk karyawan, apabila seorang karyawan mendapatkan kompensasi yang pantas atas apa yang sudah dikerjakan pada perusahaan maka karyawan tersebut juga akan mendapatkan kepuasan kerja yang baik (Hasibuan, 2016).

Variabel kompensasi secara langsung berpengaruh terhadap variabel Kinerja Pegawai. Pertunjukan ini kompensasi itu dalam bentuk gaji, upah, bonus, fasilitas, program perjalanan dan liburan tunjangan langsung memiliki efek positif pada kinerja karyawan. Variabel kompensasi berpengaruh langsung pada variabel Kepuasan Pegawai. Semakin tinggi kompensasi yang diberikan oleh perusahaan kepada karyawannya akan meningkatkan kepuasan karyawan. Kepuasan kerja memediasi pengaruh kompensasi terhadap kinerja karyawan. Kompensasi berpengaruh positif pada kepuasan kerja, dalam hal Ini menunjukkan bahwa kompensasi yang diberikan oleh perguruan tinggi sangat berpengaruh terhadap kepuasan kerja dosen dalam hal mengajar, guna mencapai tujuan dalam menyelesaikan pekerjaan (Ansori \& Caroline, 2018).

Menurut teori pengharapan dari motivasi dinyatakan bahwa seseorang untuk bermotivasi tinggi, bila seseorang tersebut memiliki semangat berusaha dan kinerja tinggi selain itu juga perlu disertai dengan keinginan besar untuk mendapatkan penghargaan akhir dan keinginan itu lebih harus lebih kuat dari pada faktor faktor yang bersifat negatif. Handoko (2011) menjelaskan tentang macam macam kompensasi yang diberikan pada karyawan diantaranya kompensasi finansial langsung (direct financial compensation), kompensasi finansial tidak langsung (indirect financial compensation), kompensasi non finansial (non financial compensation). akan mendapatkan kepuasan kerja yang baik.

Terdapat beberapa penelitian yang menyimpulkan bahwa kompensasi berpengaruh pada kepuasan kerja, seperti penelitian yang dilakukan oleh Nazir et al. (2013) yang menyatakan bahwa kompensasi berpengaruh positif terhadap kepuasan kerja. Rood \& Holdnak (2013) juga menyatakan bahwa kompensasi berpengaruh positif dan signifikan terhadap kepuasan kerja. Sama halnya dengan Adeoye \& Fields (2017), Salisu et al. (2016), dan Muguongo (2015) yang menyatakan bahwa kompensasi dan kepuasan kerja berpengaruh positif dan signifikan terhadap kepuasan kerja. Berdasarkan hasil penelitian sebelumnya, hipotesis yang dapat diajukan dalam penelitian ini adalah.

$\mathrm{H}_{3}$ : Kompensasi berpengaruh positif dan signifikan terhadap kepuasan kerja.

\section{METODE PENELITIAN}

Lokasi penelitian ini dilaksanakan di Alaya Resort Jembawan Ubud yang berlokasi di Jl. Jembawan 1 ,Padangtegal, Ubud, Gianyar, Bali, 80571, Email, Alayaresortjembawan@gmail.com dengan alasan dipilihnya hotel tersebut karena 
berdasarkan data hasil pra reset yang dilakukan Peneliti diperoleh informasi dari Kepala Bagian Sumber Daya Manusia (Human Resource Development/HRD) menyatakan bahwa saat ini adanya indikasi permasalahan terkait dengan rendahnya kepuasan kerja yang diduga disebabkan oleh beberapa faktor yakni Konflik Pekerjaan-Keluarga, Stres Kerja dan Kompensasi terhadap Kepuasan Kerja.

Jumlah populasi dalam penelitian ini adalah seluruh karyawan Alaya Resort Jembawan Ubud yang berjumlah 80 orang yang terdiri dari 62 orang karyawan tetap dan sudah berstatus kawin (menikah) dan 18 orang karyawan tidak tetap. Pada penelitian ini, metode penentuan sampel dilakukan dengan purposive sampling (judgmental sampling), yaitu teknik pengambilan sampel secara sengaja atau berdasarkan pertimbangan tertentu dalam memilih anggota populasi sebagai sampel. Kriteria sampel dalam penelitian ini adalah karyawan Alaya Resort Jembawan Ubud yang berstatus sebagai karyawan tetap dan sudah menikah yang diambil melalui jumlah populasi dan digunakan sebagai sampel penelitian sehingga sampel penelitian ini adalah 62 karyawan.

Pada analisis Statstika Inferensia menggunakan metode regresi linear berganda. Analisis ini digunakan untuk mengetahui pengaruh Konflik Pekerjaankeluarga $\left(\mathrm{X}_{1}\right)$, Stres Kerja $\left(\mathrm{X}_{2}\right)$, Kompensasi $\left(\mathrm{X}_{3}\right)$ dan Kepuasan Kerja $(\mathrm{Y})$. Metode ini diuji menggunakan sistem komputer berupa SPSS.21. Pengaruh variabel independen terhadap variabel dependen diuji dengan tingkat kepercayaan $95 \%$ atau $\alpha=5 \%$. Model regresi yang digunakan adalah sebagai berikut:

$$
\mathrm{Y}=\alpha+\beta 1 \mathrm{X} 1+\beta 2 \mathrm{X} 2+\beta 3 \mathrm{X} 3+\varepsilon \text {. }
$$

Keterangan:

$\mathrm{Y}=$ Kepuasan kerja

$\mathrm{X}_{1}=$ Konflik Pekerjaan Keluarga

$\mathrm{X}_{2}=$ Stress Kerja

$\mathrm{X}_{3}=$ Kompensasi

$\alpha=$ Konstanta

$\beta_{1}=$ Koefisien regresi Konflik Pekerjaan Keluarga

$\beta_{2}=$ Koefisien regresi Stres Kerja

$\beta_{3}=$ Koefisien regresi Kompensasi

$\varepsilon=$ erorr

\section{HASIL DAN PEMBAHASAN}

Penelitian ini menggunakan data primer dari kuesioner yang dijawab oleh para responden yaitu sebanyak 62 orang karyawan Alaya Resort Jembawan Ubud. Sebaran data karakteristik responden dikumpulkan untuk mengetahui profil responden penelitian. Berdasarkan hasil penelitian yang dilakukan, telah diketahui karakteristik responden meliputi jenis kelamin, usia, dan pendidikan terakhir, dimana jenis kelamin pria mendominasi dari umur 26-30 tahun, pendidikan terakhir SMA dan semuanya telah kawin. Data mengenai karakteristik responden disajikan pada Tabel 4. 
Tabel 4.

Karakteristik Responden Penelitian

\begin{tabular}{|c|c|c|c|c|}
\hline $\begin{array}{l}\text { No } \\
\cdot\end{array}$ & Kriteria & Klasifikasi & $\begin{array}{l}\text { Jumla } \\
\text { h } \\
\text { (Orang } \\
\text { ) }\end{array}$ & $\begin{array}{l}\text { Persentas } \\
\text { e }(\%)\end{array}$ \\
\hline \multirow[t]{3}{*}{1.} & Jenis Kelamin & Pria & 35 & 56,5 \\
\hline & \multirow{2}{*}{\multicolumn{2}{|c|}{ Jumlah }} & 27 & 43,5 \\
\hline & & & 62 & 100 \\
\hline \multirow{6}{*}{2.} & \multirow[t]{5}{*}{ Usia } & $18-20$ tahun & 6 & 9,7 \\
\hline & & $21-25$ tahun & 18 & 29,0 \\
\hline & & 26-30 tahun & 20 & 32,3 \\
\hline & & $31-35$ tahun & 14 & 22,6 \\
\hline & & 36-40 tahun & 4 & 6,5 \\
\hline & \multicolumn{2}{|c|}{ Jumlah } & 62 & 100 \\
\hline \multirow[t]{7}{*}{3.} & Pendidikan & SMA/SMK & 29 & 46,8 \\
\hline & \multirow[t]{5}{*}{ Terakhir } & D1 & 5 & 8,1 \\
\hline & & D2 & 3 & 4,8 \\
\hline & & D3 & 10 & 16,1 \\
\hline & & D4 & 6 & 9,7 \\
\hline & & S1 & 9 & 14,5 \\
\hline & \multicolumn{2}{|c|}{ Jumlah } & 62 & 100 \\
\hline \multirow[t]{3}{*}{4.} & Status & Kawin & 62 & 100 \\
\hline & & Belum Kawin & 0 & 0 \\
\hline & \multicolumn{2}{|c|}{ Jumlah } & 62 & 100 \\
\hline
\end{tabular}

Sumber: Data diolah, 2019

Tabel 4. menunjukkan hasil sebaran data karakteristik responden pada penelitian ini. Hasil menunjukkan bahwa sebagian besar responden berjenis kelamin pria dengan persentase sebesar 56,9\% dibanding responden wanita sebesar 43,5\%. Hal ini dapat berarti sebagian besar pekerjaan di Alaya Resort Jembawan Ubud membutuhkan tenaga pria untuk menyelesaikannya. Kelompok usia responden yang mendominasi adalah usia produktif dengan rentang usia terbanyak yakni 26-30 tahun yang memperoleh persentase sebesar 32,3\%. Sementara itu, responden dengan pendidikan terakhir SMA/SMK mendapatkan persentase terbanyak dibandingkan tingkat pendidikan yang lain yaitu sebesar 46,8\%. Hal ini dapat berarti bahwa para karyawan Alaya Resort Jembawan Ubud sebagian besar tidak menempuh pendidikan tinggi. Hasil juga menujukkan bahwa sesuai dengan teknik penentuan sampel penelitian maka seluruh responden dalam penelitian ini berstatus kawin atau sudah menikah.

Pengaruh variabel bebas yang terdiri dari variabel konflik pekerjaankeluarga, stres kerja, dan kompensasi terhadap variabel terikat yaitu kepuasan kerja dapat diketahui dengan melakukan analisis regresi linear berganda. Persamaan regresi dirumuskan sebagai berikut:

$$
\hat{Y}=\beta_{0}+\beta_{1} X_{1}+\beta_{2} X_{2}+\beta_{3} X_{3}+e
$$

$$
\begin{array}{cl}
\text { Dimana: Y } & =\text { kepuasan kerja } \\
\beta_{0} & =\text { konstanta }
\end{array}
$$




\begin{tabular}{|c|c|}
\hline$\beta_{1}, \beta_{2}, \beta_{3}$ & $=$ koefisien regresi \\
\hline $\mathrm{X} 1$ & $=$ konflik pekerjaan-keluarga \\
\hline $\mathrm{X} 2$ & $=$ stres kerja \\
\hline $\mathrm{X} 3$ & $=$ kompensasi \\
\hline $\mathrm{e}$ & $=$ error \\
\hline
\end{tabular}

Perhitungan koefisien regresi dilakukan dengan analisis regresi linear berganda melalui software SPSS 20.0, diperoleh hasil yang ditunjukan pada Tabel 5 berikut ini.

Tabel 5.

Hasil Analisis Regresi Linear Berganda

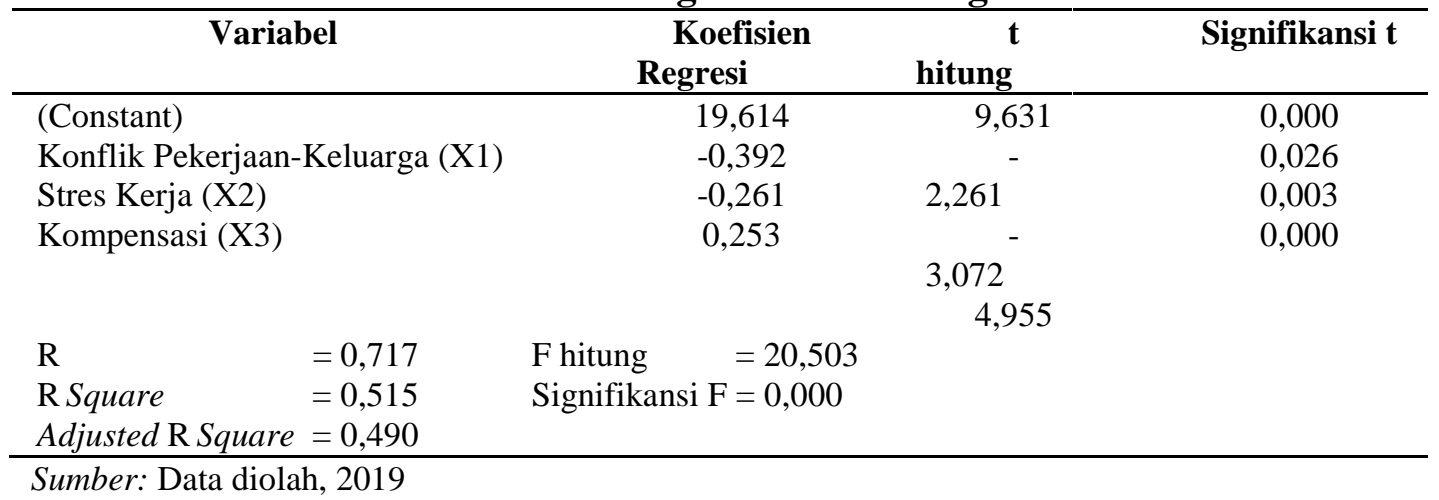

Berdasarkan Tabel 5. dapat dilihat bahwa besarnya nilai $\mathrm{R}$ square adalah sebesar 0,515 ini berarti pengaruh variabel Konflik pekerjaan keluarga, stress kerja dan kompensasi terhadap kepuasan kerja sebesar 51,5 persen sedangkan sisanya sebesar 48,5 persen dipengaruhi oleh variabel lain yang tidak masuk dalam model penelitian. Berdasarkan hasil analisis regresi linear berganda pada Tabel 5 diperoleh persamaan regresi sebagai berikut:

$$
Y=19,614-0,392 X_{1}-0,261 X_{2}+0,253 X_{3}
$$

Berdasarkan persamaan tersebut, maka variabel konflik pekerjaan keluarga, stress kerja dan kompensasi berpengaruh terhadap kepuasan kerja karyawan pada karyawan Alaya Resort Jembawan Ubud, Gianyar. Diketahui konstanta besarnya 19,614 mengandung arti jika variabel Konflik Pekerjaan Keluarga (X1), Stres Kerja (X2), Kompenasi (X3) tidak berubah, maka Kepuasan Kerja (Y) tidak mengalami perubahan atau sama dengan 19,614.

Koefisien determinasi digunakan .untuk mengetahui besarnya kontribusi yang disumbangkan variabel konflik pekerjaan-keluarga (X1), stres kerja (X2), dan kompensasi (X3) terhadap kepuasan kerja (Y) di Alaya Resort Jembawan Ubud. Hasil perhitungan koefisien determinasi ditunjukkan pada angka R Square $\left(\mathrm{R}^{2}\right)$. Nilai $\mathrm{R}$ Square sebesar 0,515 memiliki arti bahwa sebesar 51,5\% variasi kepuasan kerja di Alaya Resort Jembawan Ubud dipengaruhi oleh konflik pekerjaan-keluarga, stres kerja, dan kompensasi, sedangkan sisanya sebesar 48,5\% dipengaruhi oleh faktor lain yang tidak dimasukkan ke dalam model penelitian. 
Uji kelayakan model atau disebut sebagai uji $\mathrm{F}$ merupakan tahapan awal mengidentifikasi model regresi yang diestimasi layak atau tidak. Layak (andal) disini maksudnya adalah model yang diestimasi layak digunakan untuk menjelaskan pengaruh variabel-variabel bebas terhadap variabel terikat. Pengujian hipotesis secara simultan (uji F) juga dilakukan untuk mengetahui pengaruh variabel-variabel bebas secara bersama-sama atau simultan atas suatu variabel terikat.

Signifikansi tabel ANOVA menunjukkan besarnya angka probabilitas atau signifikansi pada perhitungan ANOVA. Nilai yang tertera digunakan untuk uji kelayanan model analisis (dimana sejumlah variabel X mempengaruhi variabel Y) dengan ketentuan angka probabilitas yang baik untuk digunakan sebagai model regresi harus kurang dari 0,05. Jika Sig. < 0,05, maka model analisis dianggap layak, jika Sig. > 0,05, maka Model Analisis dianggap tidak layak. Hasil uji F pada penelitian ini ditunjukkan pada Tabel 6 .

Tabel 6.

Hasil Uji F

\begin{tabular}{cccccc}
\hline Model & Sum of Squares & df & Mean Square & F & Sig. \\
\hline Regression & 68,635 & 3 & 22,878 & 20,503 & 0,000 \\
Residual & 64,720 & 58 & 1,116 & & \\
Total & 133,355 & 61 & & & \\
\hline
\end{tabular}

Sumber: Data diolah, 2019

Berdasarkan Tabel 6, nilai signifikansi $\mathrm{F}$ adalah sebesar 0,000 yang lebih kecil dari 0,05 yang berarti variabel bebas yaitu konflik pekerjaan-keluarga (X1), stres kerja (X2), dan kompensasi (X3) berpengaruh signifikan secara serempak atau bersama-sama terhadap variabel terikat yaitu kepuasan kerja (Y) di Alaya Resort Jembawan Ubud, sehingga penelitian ini dapat dikatakan memenuhi uji kelayakan model atau model penelitian dinyatakan layak digunakan sebagai model regresi.

Berdasarkan hasil uji t, diketahui bahwa variabel konflik pekerjaan-keluarga memiliki nilai koefisien beta negatif sebesar $-0,392$ dengan nilai signifikansi sebesar 0,026. Nilai koefisien beta $<0$ dan nilai signifikansi $<0,05$ mengindikasikan bahwa konflik pekerjaan-keluarga berpengaruh negatif dan signifikan terhadap kepuasan kerja. Dengan demikian, H1 diterima.

Berdasarkan hasil uji t, diketahui bahwa variabel kompensasi memiliki nilai koefisien beta positif sebesar 0,253 dengan nilai signifikansi sebesar 0,000. Nilai koefisien beta $>0$ dan nilai signifikansi $<0,05$ mengindikasikan bahwa stres kerja berpengaruh positif dan signifikan terhadap kepuasan kerja. Dengan demikian, H3 diterima.

Berdasarkan hasil pengujian hipotesis pertama, diperoleh nilai koefisien beta sebesar $-0,392$ dengan signifikansi sebesar 0,026 . Nilai koefisien beta yang memiliki arah positif serta nilai signifikansi yang lebih kecil dari tingkat probabilitas 0,05 mengartikan bahwa $\mathrm{H}_{0}$ ditolak dan $\mathrm{H}_{1}$ diterima. Hasil dari pengujian ini adalah konflik pekerjaan-keluarga berpengaruh negatif dan signifikan terhadap kepuasan kerja. Artinya, apabila tingkat konflik pekerjaankeluarga rendah maka kepuasan kerja para karyawan Alaya Resort Jembawan 
Ubud akan semakin tinggi. Sebaliknya, jika tingkat konflik pekerjaan-keluarga tinggi maka kepuasan kerja para karyawan Alaya Resort Jembawan Ubud akan semakin rendah.

Hasil penelitian ini memperkuat beberapa penelitian sebelumnya yang telah membuktikan bahwa konflik pekerjaan-keluarga berpengaruh negatif dan signifikan terhadap kepuasan kerja seperti penelitian yang dilakukan Kurnia (2016), Soeharto (2010), Prawitasari \& Purwanto (2007), dan Nawab \& Iqbal (2013).

Berdasarkan hasil pengujian hipotesis kedua, diperoleh nilai koefisien beta sebesar -0,261 dengan signifikansi sebesar 0,003. Nilai koefisien beta yang memiliki arah negatif serta nilai signifikansi yang lebih kecil dari tingkat probabilitas 0,05 mengartikan bahwa $\mathrm{H}_{0}$ ditolak dan $\mathrm{H}_{2}$ diterima. Hasil dari pengujian ini adalah stres kerja berpengaruh negatif dan signifikan terhadap kepuasan kerja. Artinya, apabila tingkat stres kerja rendah maka kepuasan kerja para karyawan Alaya Resort Jembawan Ubud akan semakin tinggi. Sebaliknya, jika tingkat stres kerja tinggi maka kepuasan kerja para karyawan Alaya Resort Jembawan Ubud akan semakin rendah.

Hasil penelitian ini memperkuat beberapa penelitian sebelumnya yang telah membuktikan bahwa stres kerja berpengaruh negatif dan signifikan terhadap kepuasan kerja seperti penelitian yang dilakukan Mansoor et al. (2014), Tunjungansari (2011), dan Potale \& Uhing (2015).

Berdasarkan hasil pengujian hipotesis ketiga, diperoleh nilai koefisien beta sebesar 0,253 dengan signifikansi sebesar 0,000. Nilai koefisien beta yang memiliki arah positif serta nilai signifikansi yang lebih kecil dari tingkat probabilitas 0,05 mengartikan bahwa $\mathrm{H}_{0}$ ditolak dan $\mathrm{H}_{3}$ diterima. Hasil dari pengujian ini adalah kompensasi berpengaruh positif dan signifikan terhadap kepuasan kerja. Artinya, apabila tingkat kompensasi tinggi maka kepuasan kerja para karyawan Alaya Resort Jembawan Ubud akan semakin tinggi. Sebaliknya, jika tingkat kompensasi rendah maka kepuasan kerja para karyawan Alaya Resort Jembawan Ubud akan semakin rendah.

Hasil penelitian ini memperkuat beberapa penelitian sebelumnya yang telah membuktikan bahwa kompensasi berpengaruh positif dan signifikan terhadap kepuasan kerja seperti penelitian yang dilakukan Nazir et al. (2013), Rood \& Holdnak (2013), Adeoye \& Fields (2017), Salisu et al. (2016), Muguongo (2015), Darma \& Supriyanto (2017), Ansori \& Caroline (2018), serta Wijaya et al. (2018).

Implikasi penelitian ini menekankan pada manfaat nyata dari hasil penelitian yang telah dilakukan. Penelitian ini menggunakan pendekatan konflik pekerjaan-keluarga, stres kerja, dan kompensasi yang merupakan pengaruh langsung dari kepuasan kerja. Konflik pekerjaan-keluarga terbukti secara negatif mempengaruhi kepuasan kerja, oleh karena itu penting bagi manajemen Alaya Resort Jembawan Ubud untuk memperhatikan beban pekerjaan yang diberikan pada karyawan agar mereka dapat menyeimbangkan tugas di tempat kerja dengan kehidupan di rumah sehingga tidak merasakan adanya kesenjangan antara pekerjaan dan keluarga. Stres kerja terbukti secara negatif mempengaruhi kepuasan kerja, oleh karena itu penting bagi manajemen Alaya Resort Jembawan 
Ubud untuk memperhatikan faktor-faktor yang menyebabkan stres kerja karyawan di tempat kerja serta merangkul dan mengevaluasi para karyawan dengan tingkat stres kerja yang tinggi agar tidak tertekan dalam menghadapi pekerjaan.

Kompensasi terbukti secara positif mempengaruhi kepuasan kerja, oleh karena itu sistem kompensasi yang diberlakukan manajemen Alaya Resort Jembawan Ubud hendaknya menyesuaikan pada beban kerja dan kinerja karyawan sehingga karyawan merasa diapresiasi melalui imbalan yang setara tersebut. Selain itu, terlihat dari hasil kuisioner ada sejumlah karyawan yang merasa pekerjaannya kurang menarik dan tidak sesuai kemampuan, untuk mengatasi hal ini sebaiknya juga perlu dilakukan training atau penyesuaian posisi atau jenis pekerjaan sehingga mampu memberikan rasa puas dalam bekerja. Kepuasan kerja akan timbul dan meningkat apabila manajemen secara berkelanjutan memperhatikan konflik pekerjaan-keluarga, stres kerja, serta kompensasi para karyawannya. Terciptanya kepuasan kerja karyawan yang tinggi akan memberikan manfaat pada perusahaan itu sendiri karena para karyawan akan berusaha meberikan performa kinerja yang sebaik-baiknya.

Dalam melaksanakan penelitian ini juga Peneliti mengalami beberapa kendala atau keterbatasan penelitian yaitu subyek penelitian ini hanya satu perusahaan yakni Alaya Resort Jembawan Ubud, tentu saja hasil tersebut tidak dapat dilakukan generalisasi bahwa penelitian yang sama, dengan subyek yang lebih beragam akan memberikan hasil dan temuan-temuan yang sama.

Jumlah sampel dalam penelitian ini berjumlah 62 responden, dimana jumlah ini relatif sedikit sehingga memiliki tingkat generalisasi rendah. Diharapkan untuk penelitian selanjutnya dapat menggunakan sampel yang berasal dari beberapa klas lembaga pemasyarakatan yang berbeda. Penelitian ini hanya menggunakan work family conflict, stress kerja dan kompensasi sebagai prediktor kepuasan kerja. Diharapkan untuk penelitian selanjutnya menggunakan variabel yang lebih banyak misalnya motivasi, disiplin kerja, kepribadian, faktor kepemimpinan, dan sebagainya.

\section{SIMPULAN}

Konflik pekerjaan-keluarga berpengaruh secara negatif dan signifikan terhadap kepuasan kerja. Hasil ini menunjukkan bahwa apabila konflik pekerjaankeluarga tinggi, maka kepuasan kerja para karyawan Alaya Resort Jembawan Ubud akan semakin rendah. Sebaliknya, jika konflik pekerjaan-keluarga rendah maka kepuasan kerja para karyawan Alaya Resort Jembawan Ubud akan meningkat. Stres kerja berpengaruh secara negatif dan signifikan terhadap kepuasan kerja. Hasil ini menunjukkan bahwa apabila stres kerja tinggi, maka kepuasan kerja para karyawan Alaya Resort Jembawan Ubud akan semakin rendah. Sebaliknya, jika stres kerja rendah maka kepuasan kerja para karyawan Alaya Resort Jembawan Ubud akan meningkat. Kompensasi berpengaruh secara positif dan signifikan terhadap kepuasan kerja. Hasil ini menunjukkan bahwa apabila kompensasi tinggi, maka kepuasan kerja para karyawan Alaya Resort Jembawan Ubud akan meningkat. Sebaliknya, jika kompensasi rendah maka 
kepuasan kerja para karyawan Alaya Resort Jembawan Ubud akan senakin rendah.

Peningkatan perhatian pada faktor-faktor yang mempengaruhi konflik pekerjaan-keluarga menjadi penting karena ketika para karyawan Alaya Resort Jembawan Ubud merasa tidak adanya kesenjangan antara pekerjaan dan keluarga, maka kepuasan kerja akan meningkat. Manajemen Alaya Resort Jembawan Ubud hendaknya selalu memperhatikan faktor-faktor yang menyebabkan stres kerja karyawan di tempat kerja serta merangkul dan mengevaluasi para karyawan dengan tingkat stres kerja yang tinggi agar tidak tertekan dalam menghadapi pekerjaan. Hal tersebut demi meningkatkan kepuasan kerja karyawan. Kompensasi yang diberikan oleh perusahaan kepada para karyawan hendaknya diatur secara benar dan adil agar sumber daya manusia perusahaan memberikan timbal balik yang positif khususnya dalam peningkatan kepuasan kerja sehingga kinerja karyawan akan semakin baik. Peneliti selanjutnya diharapkan untuk melakukan penelitian dengan cakupan yang lebih luas, menambah variabelvariabel lain di luar penelitian ini serta diharapkan mampu menambah referensi terhadap variabel yang akan diteliti.

\section{REFERENSI}

Adeoye, A. O., \& Fields, Z. (2017). Compensation Management and Employee Job Satisfaction: A Case of Nigeria. Journal of Social Sciences, 41(3), 345352. https://doi.org/10.1080/09718923.2014.11893369

Ali Shurbagi, A. M. (2014). The Relationship between Transformational Leadership Style Job Satisfaction and the Effect of Organizational Commitment. International Business Research, 7(11), 126-138. https://doi.org/10.5539/ibr.v7n11p126

Ammiriel Kusumoayu Prawitasari, Yadi Purwanto, S. Y. (2007). Hubungan workfamily conflict dengan kepuasan kerja pada karyawati berperan jenis kelamin androgini di pt. tiga putera abadi perkasa cabang purbalingga. Jurnal Ilmiah Berkala Psikologi, 9(2), 1-13.

Anafarta, N. (2011). The Relationship between Work-Family Conflict and Job Satisfaction: A Structural Equation Modeling (SEM) Approach. International Journal of Business and Management, 6(4), 168-177. https://doi.org/10.5539/ijbm.v6n4p168

Ansori, M., \& Caroline, C. (2018). Influence of Compensation and Working Condition on Job Satisfaction and Commitment of Lecturers at the College, $3(1), 64-72$.

Ardana, Mujiati, N. W., \& Sriathi, A. A. . (2013). Perilaku Keorganisasian (2nd ed.). Yogyakarta: Graha Ilmu.

Bhatti, W. A., Zaheer, A., \& Rehman, K. U. (2011). The effect of knowledge management practices on organizational performance: A conceptual study. 
African Journal of Business Management, 5(7), 2847-2853. https://doi.org/10.5897/AJBM10.1277

Churiyah, M. (2011). Pengaruh Konflik Peran, Kelelahan Emosional terhadap Kepuasan Kerja dan Komitmen Organisasi. Jurnal Ekonomi Bisnis, 2(16), 145-154. Retrieved from http://fe.um.ac.id/wp-content/uploads/2009/10/8Madziatul-Churiyah.pdf

Darma, P. S., \& Supriyanto, A. S. (2017). The Effect of Compensation on Satisfication and Employe Perfomance. Management and Economics Journal, 1(1), 1-19.

Dehghan Nayeri, N., Dibaji Forooshani, Z. S., \& Arabloo, J. (2018). The study of work-family conflict and job satisfaction among nurses' state hospitals in Tehran city. Electronic Physician, 10(5), 6864-6867. https://doi.org/10.19082/6864

Ding, X., Yang, Y., Su, D., Zhang, T., Li, L., \& Li, H. (2018). Can job control ameliorate work-family conflict and enhance job satisfaction among Chinese registered nurses? A mediation model. International Journal of Occupational and Environmental Medicine, 9(2), 97-105. https://doi.org/10.15171/ijoem.2018.1176

Ehsan Malik, M., Qaiser Danish, R., \& Munir, Y. (2012). The Impact of Pay and Promotion on Job Satisfaction: Evidence from Higher Education Institutes of Pakistan. American Journal of Economics, 2(4), 6-9. https://doi.org/10.5923/j.economics.20120001.02

Grandey, A. A., Cordeiro, B. L., \& Crouter, A. C. (2005). A longitudinal and multi-source test of the work-family conflict and job satisfaction relationship. Journal of Occupational and Organizational Psychology, 78(3), 305-323. https://doi.org/10.1348/096317905X26769

Handoko., T. H. (2011). Manajemen Personalia dan Sumberdaya Manusia (2nd ed.). Yogyakarta: Penerbit BPFE.

Hasibuan, M. S. . (2016). Manajemen Sumber Daya Manusia (Revisi). Jakarta: Bumi Aksara.

Henry, O. (2009). Organisational Conflict and its Effects on Organisational Performance. Research Journal of Business Management, 3(1), 16-24. https://doi.org/10.3923/rjbm.2009.16.24

Jehangir, M., Nasir, K., Tahir, A. M., \& Soherwardi, S. (2011). Effects of Job Stress on Job Performance and Job Satisfication. Interdisciplinary Journal Of Contemporary Research In Business, 13(7), 567-693.

Karambut, C., \& Noormijati, E. A. T. (2015). Analisis Pengaruh Kecerdasan Emosional , Stres Kerja dan kepuasan Kerja terhadap Komitmen Organisasional (Studi pada Perawat Unit Rawat Inap RS panti Waluya Malang). Jurnal Aplikasi Manajemen, 10(3), 655-668. 
Karimi, Q., Jomehri, F., Asadzade, H., \& Sohrabi, F. (2012). Consequences of Conflict between Work and Family among Iranian Female Teachers. Journal of Basic and Applied Scientific Research, 2(2), 1869-1875.

Kurnia, A. L. (2016). Analisis Pengaruh Kepuasan Kerja, Komitmen Organisasi, Stres kerja terhadap Turnover Intention Auditor dengan Kinerja Auditor sebagai Variabel Moderating. Skripsi. Sarjana Akuntansi Fakultas Ekonomi Universitas Negeri Semarang.

Laksmi, N. A. ., \& Hadi, C. (2012). Hubungan antara Konflik Peran Ganda (Work Family Conflict) dengan Kepuasan Kerja pada Karyawati bagian Produksi PT.X. Jurnal Psikologi Industri Dan Organisas, 1(02), 124-130.

Lathifah, \& Rohman. (2014). The Influence of Work-Family Conflict on Turnover Intentions with Job Satisfication as an Intervening Variable on Public Accountant Firms in Indonesia. International Journal of Reserach in Business and Technology, 5(2), 617-625.

Luthan, F. (2008). Perilaku Organisasi (10th ed.). Yogyakarta: Andi.

Makena Muguongo, M. (2015). Effects of Compensation on Job Satisfaction Among Secondary School Teachers in Maara Sub - County of Tharaka Nithi County, Kenya. Journal of Human Resource Management, 3(6), 47. https://doi.org/10.11648/j.jhrm.20150306.11

Mamik Eko Supatmi, Umar Nimran, \& Hamidah Nayati Utami. (2013). Pengaruh Pelatihan, Kompensasi terhadap Kepuasan Kerja Karyawan dan Kinerja Karyawan. Jurnal Administrasi Bisnis, 7(1), 25-37. https://doi.org/10.9876/10.9876/VOL1ISSN1978-743X

Mansoor, M., Fida, S., Nasir, S., \& Ahmad, Z. (2014). The Impact of Job Stress on Employee Job Satisfaction A Study on Telecommunication Sector of Pakistan. Journal of Business Studies Quarterly, 2(3), 50-56. https://doi.org/10.1111/j.1468-5922.2007.00690.x

Nawab, S., \& Iqbal, S. (2013). Impact of Work-Family Conflict on Job Satisfaction and Life Satisfaction. Journal of Basic and Applied Scientific Research, 3(7), 101-110.

Nazir, T., Hussain, S. F., \& Zaman, K. (2013). Impact of Rewards and Compensation on Job Satisfication: Public and Private Universities of UK. Journal of Scientific Research, 14(3), 394-403.

Noor, N. N., Rahardjo, K., \& Ruhana, I. (2014). Pengaruh Stres Kerja dan Kepuasan Kerja Terhadap Kinerja Karyawan Pada P.T. Lie Fung Surabaya. Jurnal Administrasi Bisnis, 1(2), 1-20.

Pangewa, M. (2005). Perilaku Keorganisasian. Jakarta: Departemen Pendidikan Nasional.

Peni Tunjungansari. (2011). Pengaruh Stress Kerja terhadap Kepuasan Kerja 
Karyawan pada Kantor Pusat PT. Pos Indonesia (Persero) Bandung. Universitas Komputer Indonesia, 1(1), 1-14.

Potale, R., \& Uhing, Y. (2015). Pengaruh Kompensasi Dan Stres Kerja Terhadap Kepuasan Kerja Karyawan Pada Pt. Bank Sulut Cabang Utama Manado. Jurnal Riset Ekonomi, Manajemen, Bisnis Dan Akuntansi, 633(1), 63-73.

Praptini, Y. (2001). Pengaruh Stress Kerja terhadap Kepuasan Kerja Tenaga Edukatif Tetap. Jurnal Dinamika Sosial, 2(1), 2-10.

Prawitasari, P. P., Dewa, I., Badera, N., Kunci, K., Pengawas, :, Kinerja, I., \& Profesional, K. (2015). Pengaruh Independensi, Keahlian Profesional, Dan Pengalaman Kerja Pada Kinerja Pengawas Koperasi Serba Usaha. Jurnal Akuntansi Universitas Udayana, 111, 2302-8556.

Putra, I. G. S., \& Wibawa, I. M. A. (2014). Pengaruh Stress Kerja dan Komitmen Organisasi terhadap Kepuasan Kerja Berdasarkan Gender pada Warong Miyabi Bali. E-Jurnal Akuntansi Universitas Udayana, 3(9), 2745-2766.

Rantika, R., \& Sunjoyo. (2011). Pengaruh Konflik Kerja-Keluarga Terhadap Komitmen Oragnisasi yang Dimediasi oleh Kepuasan Kerja Pada Profesi Perawat di Rumah Sakit Umum Daerah (RSUD) DR. Moewardi Surakarta. Jurnal Manajemen Teori Dan Terapan, 4(2), 28-43. Retrieved from https://e-journal.unair.ac.id/JMTT/article/viewFile/2418/1773

Rathi, N., \& Barath, M. (2013). Work-family conflict and job and family satisfaction: Moderating effect of social support among police personnel. Equality, Diversity and Inclusion, 32(4), 438-454. https://doi.org/10.1108/EDI-10-2012-0092

Rood, A. S., \& Holdnak, A. (2013). An Analysis of Compensation Patterns and Job Satisfaction Issues of Resort Recreation Professionals. Journal of Tourism Insights, 4(1). https://doi.org/10.9707/2328-0824.1038

Salisu, J. B., Chinyio, E., \& Suresh, S. (2016). The impact of compensation on the job satisfaction of public sector construction workers of jigawa state of Nigeria. The Business and Management Review, 6(4), 10-11. Retrieved from

http://www.abrmr.com/myfile/conference_proceedings/Con_Pro_66154/201 5iacp47.pdf

Simamora, H. (2004). Manajemen Sumber Daya Manusia (3rd ed.). Yogyakarta: STIE YKPN.

Slocum, \& Helriegel. (2007). Technostress in The Workplace Managing Stress in The Electronic Workplace. Journal American Academy of Business.

Soeharto, T. N. E. D. (2010). Konflik Pekerjaan Keluarga dengan Kepuasan Kerja : Metaanalisis. Jurnal Psikologi, 37(1), 189-194.

Susanto. (2010). Analisis Pengaruh Konflik Kerja-Keluarga terhadap Kepuasan 
Kerja Pengusaha Wanita di Kota Semarang. Aset, 12(1), 75-85.

V, R., \& Sagala, E. . (2011). Manajemen Sumber Daya Manusia untuk Perusahaan (2nd ed.). Jakarta: Rajagrafindo Persada.

Velnampy, P. T. (2013). Occupational Stress and Organizational Commitment in Private Banks: A Sri Lankan Experience. European Journal of Business and Management, 5(7), 254-267.

Waspodo, A. A., Nurul Chotimah Handayani, \& Widya Paramita. (2013). Pengaruh Kepuasan Kerja dan Stress Kerja terhadap Turnover Intention pada Karyawan PT. Unitex di Bogor. Jurnal Riset Manajemen Sains Indonesia, 4(1), 97-115.

Wibowo. (2016). Manajemen Kinerja. Jakarta: PT. Raja Grafindo Persada.

Wijaya, N. S., Darsana, I. M., Pantiyasa, I. W., \& Astina, I. N. G. (2018). Organization Culture, Competency, Compensation, Job Satisfication and Lecturer Loyalty. International Journal of Business on Hospitality and Tourism, 4(1), 1-19.

Yekti, M., \& Wulandari, A. (2010). Cara jitu Mengatasi Stres. Yogyakarta: Andi. 